\title{
Myxobolus cycloides on the swimbladder of chub Leuciscus cephalus: a controlled, host-specific localisation
}

\author{
Astrid S. Holzer*, Oskar Schachner \\ Institute of Hydrobiology and Ichthyology, Vienna University of Veterinary Sciences, 1210 Vienna, Austria
}

\begin{abstract}
Of 150 wild stock chub, Leuciscus cephalus L. captured in Lower Austrian watercourses, 112 revealed disc like plasmodia of Myxobolus cycloides Gurley, 1893 on the caudal chamber of the swim bladder. Other cyprinid species from the same waters lacked $M$. cycloides or other myxosporeans in this specific localisation. In chub, the intensity of infection (number of discs on the swim bladder) showed a logarithmic, age-dependent increase. The plasmodia of M. cycloides were situated in the connective tissue - mainly along blood vessels - and exhibited a delicate envelope of host tissue, thus forming a characteristic myxosporean cyst. Occasionally single trophozoites seemed to merge. A general process of fibroblast proliferation leading to encapsulation and degradation of the parasite was observed. This process was initiated by the formation of small multiple encapsulations within the spore containing trophozoid, before thickening of the outer cyst wall occurred. The general noninflammatory course of the $M$. cycloides infection, and the obvious good health of the investigated chub suggest that this myxosporean in its host specific localisation cannot be regarded as a serious pathogen - on the contrary: parasite multiplication and degradation seemed to occur in a welldefined equilibrium controlled by the host fish.
\end{abstract}

KEY WORDS: Myxobolus cycloides $\cdot$ Leuciscus cephalus $\cdot$ Swim bladder $\cdot$ Inflammation

\section{INTRODUCTION}

The chub Leuciscus cephalus L. is widely distributed throughout Europe; the only regions where it is not found are Denmark, Northern Scotland, Southwest England, Ireland, and Northern Scandinavia. As a highly euryoecious species, the chub appears in flowing waters as well as lakes and even brackish water. Due to its economical unimportance the chub has not been looked at in detail. Only recently our interests have moved to this species because preliminary examinations of wild stock cyprinids from Austrian rivers showed an outstanding prevalence of myxosporea in the chub when compared with other cyprinid species.

In European reared carp fry, Cyprinus carpio L., a common disease (Dyková \& Lom 1988) is sphaero-

*E-mail: a.s.holzer@stir.ac.uk sporosis of the kidney caused by Sphaerospora renicola Dyková \& Lom, 1982. This infection is accompanied by heavy inflammation of the swim bladder which contains masses of developmental stages of the parasite (Körting 1982, Csaba et al. 1984, Molnar 1984, Molnar \& Kovacs-Gayer 1986). In culture, losses may reach 70 to $100 \%$ of carp fry populations (Grupcheva et al. 1985).

Pathological swim bladder changes in wild stock cyprinids are rarely reported. In Slovenia they are ascribed to releases from fish farms into adjacent ponds and lakes (Ocvirk \& Snoj 1983). These authors mention the occurrence of swim bladder inflammations in chub but do not associate the disease with Sphaerosposa renicola or other myxosporeans. The striking presence of macroscopic visible trophozoites on the swim bladder of wild stock chub examined in our laboratory provoked a study, with the objective to 
determine which, and how frequently, myxosporean species occur on the swim bladder, and where they are located. An additional purpose was to find out if the presence of myxosporeans is associated with pathological swim bladder changes in chub, similar to the conditions in cultured carp fry.

\section{MATERIALS AND METHODS}

A total of 150 wild stock chub Leuciscus cephalus ranging from 5 up to $50 \mathrm{~cm}$ in body length, were captured by electro-fishing in Lower Austrian watercourses between June 1997 and October 1998, and kept in flow-through water tanks up to $1 \mathrm{wk}$ before examination. Additionally, a total of 60 other randomly sampled cyprinids (Table 1) of the same fish populations were examined using the same methods.

The swim bladder and several other organs were scrutinised macro- and microscopically for the presence of myxosporea. The number of trophozoites, visible with the naked eye, were counted and their diameter measured. Rank correlation between the number of trophozoites and fish size was determined according to Spearman.

Fresh smears and $4 \mu \mathrm{m}$ histological sections of $4 \%$ buffered formaldehyde-fixed organ portions, embedded in paraplast after conventional dehydration, were examined. The sections were stained with (1) haematoxylin and eosin (H\&E), (2) Gram reaction, followed by nuclear red and a $0.35 \%$ solution of aniline blue in picric acid (Schachner \& Holzer 2001), and (3) mordant red counterstained with methylen blue.
Table 1. Number and species of cyprinid individuals examined

\begin{tabular}{|rl|}
\hline Number & Species \\
\hline 150 & Leuciscus cephalus L. \\
6 & Abramis sapa L. \\
5 & Alburnus alburnus L. \\
3 & Abramis abramis L. \\
20 & Blicca bjoerkna L. \\
5 & Carassius auratus gibelio Bloch \\
8 & Carassius carassius L. \\
3 & Gobio gobio L. \\
2 & Rhodeus sericeus amarus Bloch \\
8 & Rutilus rutilus L. \\
\hline
\end{tabular}

bladder where they were mainly situated close to blood vessels (Fig. 1) in the loosely packed connective tissue between the Tunica serosa and the Tunica muscularis (Fig. 2a). The plasmodia were surrounded by a delicate envelope of connective tissue, thus forming a characteristical myxosporean cyst. Fibroblasts were also discernible inside the parasitic complex (Fig. 2d).

In smears of these trophozoites, all stages of spore maturity were found: small cell-in-cell formations as well as pansporoblasts containing 2 (occasionally 1 to 5 ) mature spores of Myxobolus cycloides (Fig. 2b,c). The spores measured 12.5 to $16 \mu \mathrm{m}$ (length) $\times 8$ to $10 \mu \mathrm{m}$ (width), were oval in shape, and displayed up to 6 sutural markings in the posterior region. The spores revealed a wide intercapsular processus clearly separating the 2 polar capsules, which contained a coiled filament, wound 4 to 5 times. The morphological features matched the published descriptions of M. cycloides (Lom \& Dyková 1992, 1995).

\section{RESULTS}

The swim bladders of 112 chub Leuciscus cephalus (equalling $75 \%$ ) were infected with Myxobolus cycloides Gurley, 1893, while myxosporea were generally absent on this organ in all other cyprinid species examined. All chub were apparently healthy at the time of capture, and in aquaria most of them fed to satiation.

The macroscopic plasmodia of Myxobolus cycloides on the swim bladder had a diameter of 0.2 to $4 \mathrm{~mm}$ and a characteristic, flat, disc-shaped appearance. Occasionally neighbouring discs merged to form elongated white patches. The occurrence of plasmodia was restricted to the strongly vascularised caudal chamber of the swim

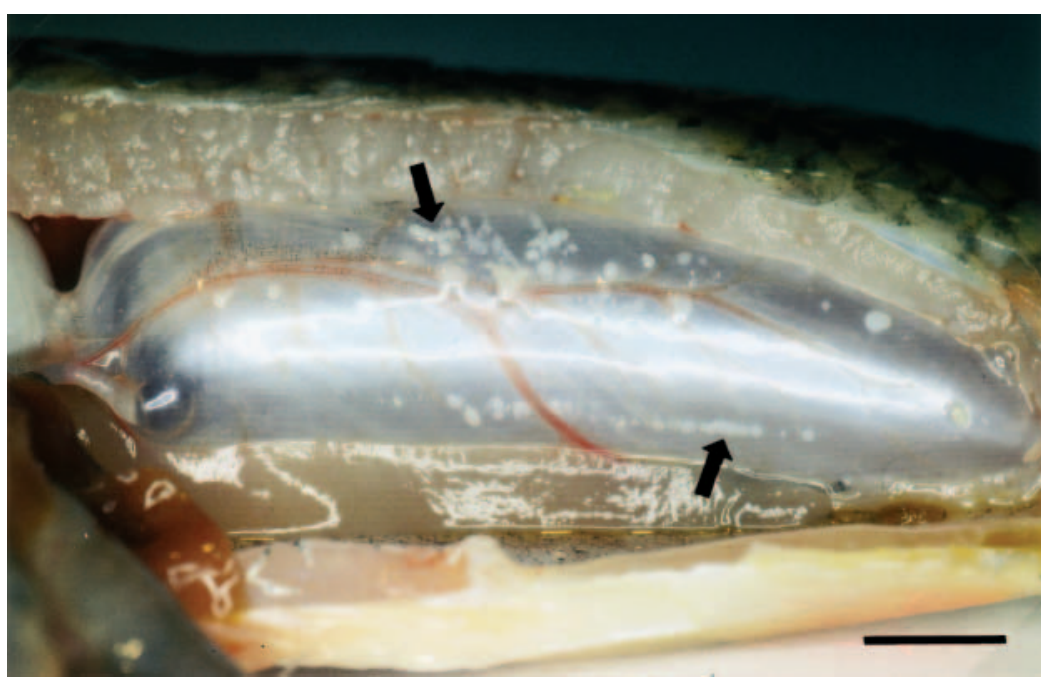

Fig. 1. Disc-shaped plasmodia of Myxobolus cycloides close to blood vessels on the caudal chamber of the swim bladder of Leuciscus cephalus; arrows indicate fusion of single trophozoites. (Scale bar $=1 \mathrm{~cm}$ ) 

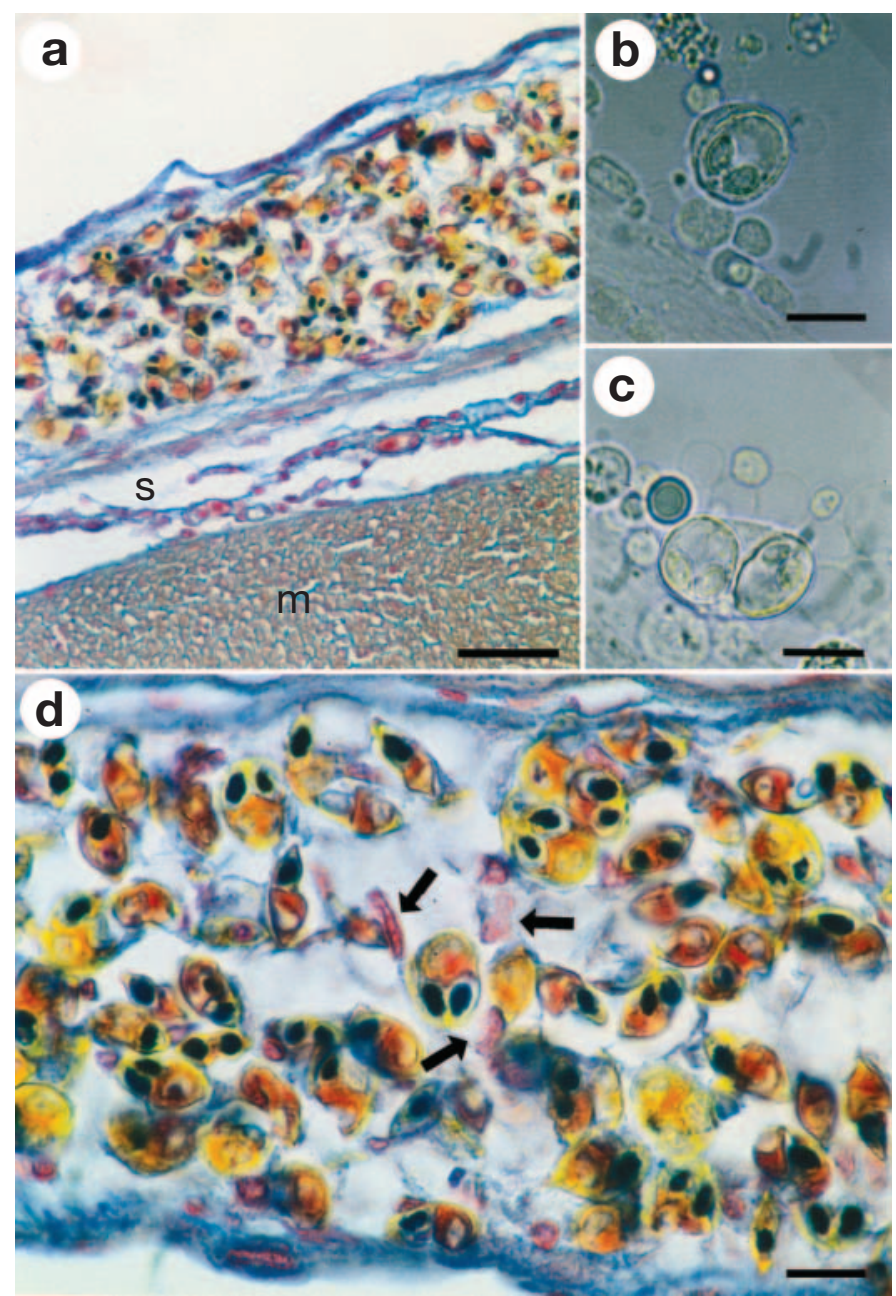

Fig. 2. Myxobolus cycloides. (a) Section through a plasmodium embedded in the connective tissue between the Tunica serosa (s) and the Tunica muscularis (m) (Gram, nuclear fast red and aniline blue in picric acid; scale bar $=30 \mu \mathrm{m}$ ); (b) monosporogonic sporoblast; (c) disporogonic sporoblast (b,c: fresh mounts); (d) trophozoit invaded by fibroblasts, arrows indicating some of the fibroblast nuclei (Gram, nuclear fast red and aniline blue in picric acid). (Scale bars in $b-d=10 \mu \mathrm{m})$

A general pattern of host tissue response to the infection of the swim bladder was observed, resulting in disintegration of the parasite: The initial stage was characterised by the migration of fibroblasts into the trophozoites and their proliferation inside the parasite units. The fibroblasts then differentiated, forming multiple fibrous encapsulations of small spore groups (2 to 15 spores) inside the plasmodium (Fig. 3a). The walls of these internal encapsulations thickened by proliferation of host cells before the envelope of the cyst as a whole became multi-layered. The contents of the cyst then underwent coagulative necrosis, hardened, and finally became calcified, revealing a deep purple
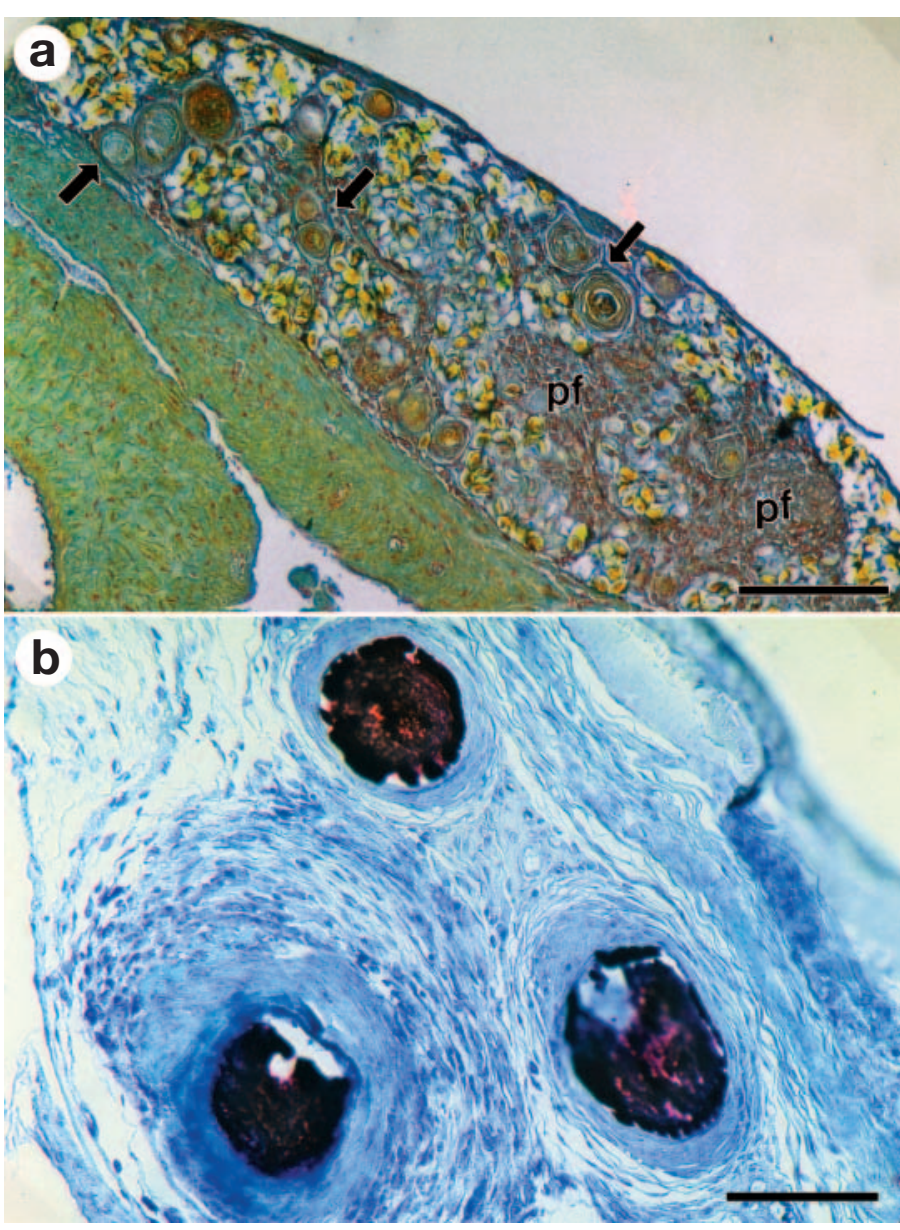

Fig. 3. (a) Areas with heavy proliferation of fibroblasts (pf) and multiple fibrous encapsulations (arrows) inside a Myxobolus cycloides tropozoit (Gram, nuclear fast red and aniline blue in picric acid; scale bar $=100 \mu \mathrm{m}$ ); (b) encapsulations with multilayered connective tissue envelope and calcified cyst contents (mordant red and methylene blue; scale bar $=50 \mu \mathrm{m}$ )

mordant red reaction (Fig. 3b). A small number of epitheloid macrophages surrounding the cores of not yet fully hardened encapsulations were involved in this process of spore degradation, but elevated numbers of granulocytes or other cells indicating inflammatory responses was not observed. Apart from the local increase of connective tissue, neither changes in other swim bladder layers, nor opacity or thickening of the wall as a whole were observed.

In infected fish, the number of trophozoites on the swim bladder increased with the total length of chub $(\mathrm{r}=0.408 ; \mathrm{p}<0.001)$. The main increase took place in fish up to $25 \mathrm{~cm}$ in size, while the intensity of infection varied around a relative constant mean in all bigger chub (Fig. 4). The youngest investigated fish $(<10 \mathrm{~cm})$ lacked Myxobolus cycloides trophozoites entirely. 


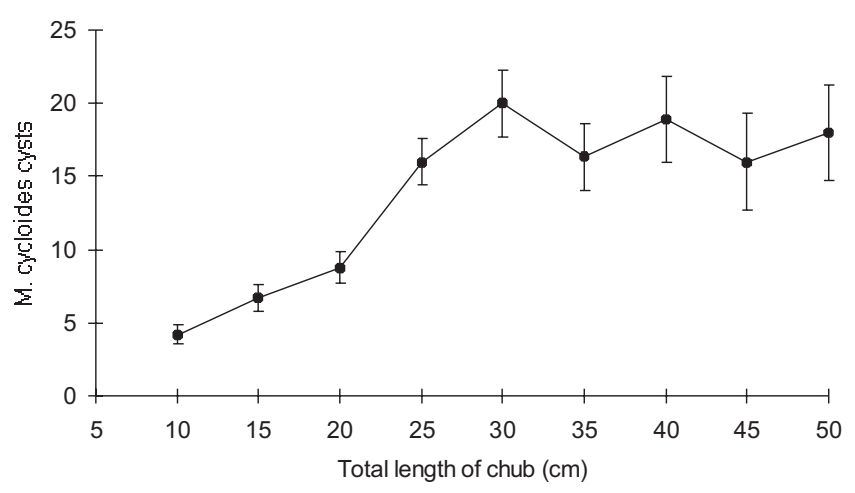

Fig. 4. Number of Myxobolus cycloides trophozoites on the swim bladder of Leuciscus cephalus of varying body lengths $($ mean $\pm \mathrm{SD})$

In $9 \%$ of chub with swim bladder trophozoites, Myxobolus cycloides occurred additionally in other sites such as, e.g. the peritoneum dorsally adjacent to the swim bladder, the mesentery, the connective tissue stroma in the liver, and the skin beneath the scales. In addition other Myxobolus species occurred frequently in the investigated chub (Holzer \& Schachner 2001).

Sometimes extrasporogonic stages with a diameter between 7 and $15 \mu \mathrm{m}$ containing small refractive inclusions were observed in the connective tissue between the trophozoites on the swim bladder. In a few cases the appearance of these stages was accompanied by minor haemorrhages around the outermost ramifications of small blood vessels.

Severe pathological changes of the swim bladder were observed in 2 chub (measuring 38 and $42 \mathrm{~cm}$ total length) which died during captivity. These deaths could not be connected with the occurrence of Myxobolus cycloides.

\section{DISCUSSION}

Myxobolus cycloides was found to infect chub Leuciscus cephalus by formation of macroscopic trophozoites on the caudal chamber of the swim bladder. Until now $M$. cycloides has been known to appear as a generalist in several organs of various cyprinid hosts (Lom \& Dyková 1992). The present investigation demonstrates specificity of this species regarding host and organ: $M$. cycloides and other myxosporeans avoid the swim bladders of other cyprinids from the same fish populations, whereas in chub this myxosporean occurs rarely in other organs than the swim bladder, which shows a remarkable prevalence of infection in chub studied of $75 \%$.

Primary infection with Myxobolus cycloides takes place in the first summer of the host's life (i.e. in fish with a total length below $10 \mathrm{~cm}$; Heuschmann 1962). The following strong increase in the number of trophozoites on the swim bladder balances out at a mean of 18 trophozoites per organ at approximately $25 \mathrm{~cm}$ body length of fish. This number is rarely exceeded in larger, even considerably so, chub. The increase is presumably not solely a result of the expansion of the organ surface in growing fish, or a possible yearly renewed infection with $M$. cycloides, because this would cause the number of trophozoites to increase with body length of chub. It is suggested that a wellbalanced equilibrium between host and parasite is established after initial infection in young fish. Above $25 \mathrm{~cm}$ body length the balance between disintegration and new formation of cysts is probably controlled by the host's immune system which should be fully developed by then. The generally observed non-inflammatory host reaction, which results in effective disintegration of the parasite, and the absence of pathologic swim bladder changes caused by $M$. cycloides, may also be ascribed to this equilibrium.

Although fish were not examined for blood stages of the parasite, the arrangement of trophozoites along blood vessels in the swim bladder suggests the blood stream as source of infection by Myxobolus cycloides. Extrasporogonic stages are supposed to be derived from the blood, to infiltrate the connective tissue and proliferate. Based on the assumption that early developmental stages of $M$. cycloides are much more mobile than mature plasmodia which are packed up in connective tissue, the observed merging of trophozoites probably takes place before maturation of the spores begins. Whether fibroblasts or -cytes serve as host cells for intracellular development or whether the commonly appearing envelope of connective tissue is built as the first step of the host tissue reaction against the parasite remains unclear, as early plasmodia lacking mature spores were not observed. However, the occurrence of $M$. cycloides, even apart from its specific localisation in the swim bladder of chub, is closely associated with connective tissue. It seems to be a question of tissue specificity rather than organ specificity, not only in the case of $M$. cycloides. Thus the common description of this myxosporean as an organ generalist might represent a degree of connective tissue specificity in different host organs.

The sufficiently available connective tissue as a source for encapsulation facilitates the process of parasite isolation from host tissue. Morrison (1983) supposed that an insufficient oxygen supply to the parasite through the connective tissue wall of xenomas of the microsporidian Loma morhua was the reason for the coagulative necrosis inside. This may also be valid for Myxobolus cycloides in chub where the spores end up in calcified indurations. 
However, the process of connective tissue proliferation and spore degradation, common in Myxobolus cycloides infection in chub, is never associated with granulomatous tissue changes as a result of a chronic inflammation and the development of a proliferative lesion progressing to form a fibrosis - as in the case of swim bladder inflammation due to Sphaerospora renicola in carp. On the contrary: The controlled noninflammatory disintegration of $M$. cycloides seems to exclude this chub-specific swim bladder myxosporean as a potential pathogen and rather mirrors an equilibrium between host and parasite, which is most likely the result of a long co-evolutionary process.

\section{LITERATURE CITED}

Csaba G, Kovács-Gayer E, Bekesi L, Bucsek M, Szakolczai J, Molnar K (1984) Studies into the possible protozoan aetiology of swimbladder inflammation in carp fry. J Fish Dis 7:39-56

Dyková I, Lom J (1988) Review of pathogenic myxosporeans in intensive culture of carp (Cyprinus carpio) in Europe. Folia Parasitol 35:289-307

Grupcheva G, Dykova I, Lom J (1985) Seasonal fluctuation in the prevalence of Sphaerospora renicola and myxosporean bloodstream stages in carp fingerlings in Bulgaria. Folia Parasitol 32:193-203

Heuschmann O (1962) Der Aitel oder Döbel. In: Demoll R,

Editorial responsibility: Wolfgang Körting,

Hannover, Germany
Maier HN (eds) Handbuch der Binnenfischerei Mitteleuropas, Bd. III B. E Schweizerbart'sche Verlagsbuchhandlung, Stuttgart, p 109-112

Holzer AS, Schachner O (2001) Myxosporea and macrophage centres in chub (Leuciscus cephalus) - quantitative interaction seems to be focused on Myxobolus cyprini. Parasitology 122:53-62

Körting W (1982) Protozoan parasites associated with swimbladder inflammation (SBI) in young carp. Bull Eur Assoc Fish Pathol 2:25-28

Lom J, Dyková I (1992) Myxosporea. In: Lom J, Dyková I (eds) Protozoan parasites of fishes. Developments in Aquaculture and Fisheries Science, Vol 26. Elsevier, Amsterdam, p 159-235

Lom J, Dyková I (1995) Myxosporea. In: Woo PTK (ed) Fish diseases and disorders, Vol 1, Protozoan and metazoan infections. CAB International, Wallingtonford, p 97-148

Molnar K (1984) Experimental evidence that protozoans causing swimm-bladder inflammation in common carp (Cyprinus carpio, L.) are stages of Sphaerospora renicola. Bull Eur Assoc Fish Pathol 4:14-15

Molnar K, Kovacs-Gayer E (1986) Experimental induction of Sphaerospora renicola (Myxosporea) infection in common carp (Cyprinus carpio) by transmission of SB-protozoans. J Appl Ichthyol 2:86-94

Morrison CM (1983) The distribution of the microsporidian Loma morhua in tissues of the cod Gadus morhua. Can J Zool 61:2155-2161

Ocvirk J, Snoj N (1983) Swim-bladder inflammation of cyprinids in Slovenia. Vet Glas 37:199-202

Schachner O, Holzer AS (2001) Gram staining and lectin binding properties of Myxosporea and Sporozoea. Biotech Histochem 76:15-22

Submitted: March 30, 2000; Accepted: November 1, 2001 Proofs received from author(s): May 22, 2002 